\title{
Consumer Protection AND FinANCIAL INCLUSION Brian Johnson
}

Thank you very much for the invitation to be here with you today. I understand that today's summit is the first event as part of Cato's new "Initiative for Financial Inclusion." Cato has been recognized for decades as a vanguard of the liberty movement, and I am grateful that your scholars, especially Todd Zywicki and Diego Zuluaga, are focused on this vital issue. We at the Bureau have much to learn from you. I look forward to a continued dialogue about your innovative policy proposals to expand access to financial services and bolster consumer protections.

My remarks today are focused on the relationship between financial inclusion and consumer protection. But before I begin, let me dispense with one minor formality: "While I am here today as a representative of the CFPB, my remarks do not constitute legal interpretation, guidance, or advice of the CFPB, and any personal opinions or views expressed are my own and may not represent the official views or position of the CFPB in all cases or in connection with specific matters."

\section{Some Basic Definitions}

Let me start with basic definitions. The phrases "financial inclusion" and "consumer protection" can mean different things to different people in different contexts, so let me clarify.

Cato Journal, Vol. 39, No. 3 (Fall 2019). Copyright (C) Cato Institute. All rights reserved. DOI:10.36009/CJ.39.3.1.

Brian Johnson is Deputy Director of the Consumer Financial Protection Bureau. This article is a lightly edited version of his luncheon address presented at Cato's June 12, 2019, conference "Financial Inclusion: The Cato Summit on Financial Regulation," sponsored by Cato's Center for Monetary and Financial Alternatives. 


\section{Cato Journal}

\section{Financial Inclusion}

For purposes of my discussion here today, financial inclusion is "the availability and equality of opportunities to access financial services." Because consumers are best off if they choose the financial services that they believe are best for them, this definition of financial inclusion implies the absence of conditions that impede the ability of consumers to make such choices.

Many conditions can thwart the ability of consumers to make these choices. Most clearly, if providers of financial services prohibit or limit consumer product choices due to unlawful discrimination, based on race or other unlawful factors, it undermines financial inclusion. Consumers can also be excluded from financial services for a variety of other reasons. Some consumers, for example, may live too far from a brick-and-mortar bank branch or other financial service provider to purchase the services they want. Other consumers may have no credit file or a thin credit file at consumer reporting agencies, which may preclude them from obtaining loans they otherwise would receive.

Now, I think the empirical research is clear, and we would all agree, that financial inclusion is positive for consumers. It facilitates income mobility, wealth-building, and consumer welfare.

And so the task before us at today's summit is to consider how best we can collectively promote financial inclusion in light of rapid technological change. One of the most obvious examples of such change is the near-ubiquity of Internet access and cell phones. According to Pew Research, for instance, 77 percent of U.S. adults now own smartphones, including a full two-thirds of adults earning less than $\$ 30,000$ per year (Smith 2017). Instant connectivity breaks down geographical divides and is a driver of a vibrant new mobile banking and FinTech ecosystem. Another example of change that holds promise is the ability of financial services providers to employ machine learning or AI to better determine creditworthiness, streamline the loan process, and generally improve the customer experience for the borrower. Like all new technology, innovations can present potential risks, but expanding financial choice and opportunity, coupled with increased market competition, undoubtedly benefits consumers and should be encouraged. Indeed, William Nordhaus (2005) famously found that, on average, consumers capture roughly 96 percent of the social returns from technological advances. 
And I realize that it is fashionable these days to refer to innovation as a new and distinct concept, but really innovation has been and always will be the main catalyst of the market system. Change and innovation are what drive market activity. Absent barriers to entry, firms that fail to satisfy constantly changing consumer preferences typically lose customers to competitors and, if they lose too many customers, they fail. Entrepreneurs are driven by market opportunities to anticipate and satisfy consumer demands.

It is therefore important to note that the free market system itself is the greatest, most powerful force on Earth for improving the financial lives of our citizens. Simply put, if one cares about the poor and financially vulnerable among us, and wants to promote financial inclusion, he or she should be a champion of our free enterprise system. Now, if you think I am overselling the power of free and competitive markets to improve all of our lives, consider for a moment a couple of remarkable facts.

First, Arthur Brooks pointed out one of the most remarkable achievements in human history: because of free enterprise, between 1970 and 2006, the proportion of the world's population living on less than a dollar a day decreased by 80 percent (Perry 2015). ${ }^{1}$ Let's think about that: in little more than three and a half decades, the proportion of people across the globe living in extreme poverty decreased by 80 percent. Millions of souls were lifted out of grinding deprivation. This is remarkable. There is simply no precedent for the improvement of human life on this vast scale in such a short amount of time.

Or consider an even longer time horizon. Two centuries ago the average world income was about $\$ 3$ a day in today's money. It's now $\$ 33$ a day. And the average American worker today earns about $\$ 130$ a day. The economist Deirdre McCloskey calls this "The Great Enrichment." It was driven by what she calls "the liberation of ordinary people to pursue their dreams of economic betterment" (McCloskey 2016). Indeed, billions of people have been lifted out of poverty because of market activity. As Milton Friedman once said, "there has never been a more effective machine for eliminating poverty than the free [market] system" (quoted in National Review Editors 2012).

\footnotetext{
${ }^{1}$ The data come from Pinovskiy and Sala-i-Martin (2009).
} 


\section{Cato Journal}

Now, if we agree that financial inclusion benefits consumers, and that the single biggest driver of financial inclusion is economic growth facilitated by free markets, it stands to reason that our legal and regulatory framework should promote free enterprise. This consideration is particularly important for the CFPB. The Bureau was created to protect consumers by ensuring, among other things, that consumer financial markets operate transparently and efficiently to facilitate access and innovation. This brings me to the second phrase requiring definition: consumer protection.

\section{Consumer Protection}

People use this malleable phrase in different senses, and these differences create confusion, particularly when discussing policy proposals. At worst, the phrase is used to mean roughly "all of the policies with which I personally agree." I think we can be more objective and precise.

In general, there are three distinct approaches to consumer protection. The first is requiring disclosures by businesses that inform consumers about their products and services. A key feature of disclosure-based regulation-when properly conceived-is that it reinforces market processes by ensuring consumers have access to truthful and understandable information (Zywicki 2016). These types of disclosures allow consumers to more efficiently compare similarly situated products among different sellers and decide which product they are willing and able to purchase. In other words, the disclosed information promotes consumer choice. And disclosure-based regulation facilitates financial inclusion because consumers who understand financial products are more likely to use them and thereby participate in our financial system.

The second approach to consumer protection is combatting unlawful acts or practices by market participants, including and especially those that are deceptive or discriminatory. Federal and state consumer protection laws have typically focused on improving consumer welfare and are directed at prohibiting the dissemination of information that is misleading or can create a likelihood of confusion. As former FTC Commissioner Joshua Wright (2012: 2215) put it, "The consumer welfare focus reinforces market principles because consumers' revealed preferences best demonstrate consumer desires, and consumer welfare is increased when consumers are better able to satisfy their desires through transparent and 
accurate transactions." Like the disclosure approach to consumer protection, this second approach is also both pro-consumer and promarket. And it facilitates financial inclusion by prohibiting market conduct intended to defeat consumer understanding or through unlawful discrimination to exclude consumers from participating altogether.

The third approach to consumer protection is what I call product restriction or design. This approach restricts the prices, terms, and products that consumers can choose. And this approach is not market-reinforcing. It is market-replacing because it substitutes the government's preferences for those of consumers (Zywicki 2016). And when government intervenes not to regulate market behavior, but to restrict product features, consumers usually lose. At least some consumers won't be able to obtain the products and services they understand and want, meaning they will have to look instead for a next-best alternative. By definition, they are made worse off by not obtaining the product they would have chosen in the absence of government restrictions. Taken together, this approach denies consumers the choice to which they should be entitled, representing a conscious policy of financial exclusion.

\section{Avoiding Abuses of Power and Expanding}

\section{Financial Inclusion}

There is significant risk to consumers in empowering one individual_or agency — to decide whether some consumers can't be trusted to have certain products or products with certain features, and that markets or products should be remade to that individual's or agency's satisfaction. If this anti-consumer product design approach were adopted by a future CFPB director, for example, he or she could pressure companies to alter their product offerings through consent orders, or use the confidential supervisory process to do the same. The director could even issue draconian rules that create such ominous legal risks that financial services providers won't offer products or product features that differ one iota from director-designed rules.

In prior remarks, I offered a rule of thumb to guard against such abuses, which was that, in the exercise of its authorities, the Bureau should be guided by a presumption in favor of consumer choice (see Johnson 2018). However, the best immediate safeguard for 


\section{CAto Journal}

consumers, given the Bureau's current authorities and structure, is the character and motivation of the director.

In this regard, I believe we are fortunate for Director Kraninger's open-minded and disciplined leadership. In the first six months of her tenure, she embarked upon a listening tour that included visits to our regional offices around the country where she heard from a great variety of Bureau stakeholders, including service members, consumer advocates, civil rights leaders, legal aid attorneys, bank and credit union officers, FinTech providers, and state and federal government officials. Following this listening tour, she articulated a positive vision for the Bureau focused on preventing harm to consumers and using the tools Congress gave us to fulfill that vision. This includes enforcing the law and using our supervisory process to promote a culture of compliance. Of course, among these laws are the fair lending, disclosure, and other laws Congress designed to reinforce the market and promote financial inclusion.

This also includes conducting financial education programs to ensure consumers receive timely and understandable information to make responsible decisions about financial transactions. For example, the Bureau recently launched its Start Small, Save Up initiative to help consumers build an emergency savings cushion and develop a savings habit. These efforts, too, are market-reinforcing and promote financial inclusion.

And another tool the Director identified is the use of rulemaking and guidance where appropriate to articulate clear rules of the road for regulated entities. Reducing regulatory uncertainty and identifying and addressing undue regulatory burden help promote market efficiency and competition, which can in turn help facilitate financial inclusion (see Higgs 1992, 1997). As an example of this approach, the Bureau recently proposed rules to implement the Fair Debt Collection Practices Act by clarifying among other things the application of the requirements of that law to new communications technologies.

A final tool the Director has identified is the use of innovation policies to expand financial choice and access to financial services by reducing regulatory uncertainty and incentivizing new ideas and products. On that score, the CFPB has established a new Office of Innovation and hired an Assistant Director to lead it who, prior to joining the Bureau, had successfully led efforts to establish the nation's first state FinTech Sandbox. 
Since its creation, the Office of Innovation has been busy. Under its guidance, the Bureau joined the Global Financial Innovation Network, or GFIN, an international consultative body wherein we can exchange ideas and learn best practices for promoting innovation from other government agencies with similar missions throughout the globe. The Office has also proposed three policies to help facilitate innovation.

For example, we have proposed a revised No-Action Letter Policy (NAL Policy). The program can potentially serve a variety of purposes toward improving innovation. For instance, we can clearly signal enforcement priorities at the Bureau, allowing the market to offer products in areas where there are anticipated consumer benefits. And, while the NAL Policy can be beneficial for all types of firms, it would be especially important for emerging FinTech companies. And, as contemplated in our proposal, the NAL Policy would have built into it a number of consumer safeguards to help ensure that we are promoting innovation that benefits consumers, both initially and over time.

The Bureau's proposed CFPB Product Sandbox is another tool the Office of Innovation has proposed using to expand financial inclusion. Sandboxes have broad support, at home and internationally, and rightfully so. ${ }^{2}$ They can serve to facilitate innovation in highly regulated commercial spaces. And they can provide the Bureau with a "front row seat" at early stages of product development, increasing the Bureau's institutional knowledge relating to cutting-edge financial technology. Above all, they can help regulated entities through the uncertainties posed by the application of regulations to products or product features that did not exist or were even imagined when those regulations were written.

And finally, the Bureau has also proposed a revised version of its Trial Disclosure Policy that is designed to encourage new and bold ideas related to improving disclosures—and ultimately improving consumer understanding of financial products.

The comment period on each of those policies has closed. We are reviewing comments, and working to finalize and publish the policies.

\footnotetext{
${ }^{2}$ See U.K. Fin. Conduct Authority (2015). The FCA cited four primary reasons: "[1] reducing the time and, potentially, the cost of getting innovative ideas to market; [2] enabling greater access to finance for innovators; [3] enabling more products to be tested and, thus, potentially introduced to the market; and [4] allowing the FCA to work with innovators to ensure that appropriate consumer protection safeguards are built in to their new products and services."
} 


\section{Cato Journal}

\section{Conclusion}

In closing, if some of the definitional distinctions I have drawn today-financial inclusion versus financial exclusion, consumer choice-based consumer protection versus product restriction or design, and market-reinforcing actions versus market-replacing actions - seem vaguely familiar, it is because they are new aspects of the age-old debate about liberty and security. At stake in the outcome of the debate is the very notion of consumer sovereignty. Some favor increased government authority at the expense of personal autonomy and financial liberty, but not me.

The fundamental question is this: Who do we want making financial decisions for ourselves and our children? Over a half century ago, President Reagan (1964) observed that "a government can't control the economy without controlling people." So we have come to a time for choosing. Either we accept the responsibility for our own destiny, or, as Reagan said, we "abandon the American Revolution and confess that an intellectual elite in a far-distant capitol can plan our lives for us better than we can plan them ourselves."

Fifty-five years later, we still have to make this fundamental choice. We must be vigilant, guarding against every effort to subvert the idea of consumer protection by equating it with giving license to government actors to supplant consumer preferences with their own. And we must be mindful that the free market is the greatest engine for economic mobility and financial inclusion. Quite simply, the single best policy to protect American consumers and to foster financial inclusion is to ensure that consumers have the ability to make their own choices in free markets.

\section{References}

Higgs, R. (1992) "Regime Uncertainty: Why the Great Depression Lasted So Long and Why Prosperity Resumed after the War." The Independent Review 1 (4): 561-90.

(1997) "Wartime Prosperity? A Reassessment of the U.S. Economy in the 1940s." Journal of Economic History 52 (1): $41-60$.

Johnson, B. (2018) "Toward a 21st Century Approach to Consumer Protection." Remarks to Consumer Action, November 15. Available at www.consumerfinance.gov/about-us/newsroom /toward-21st-century-approach-consumer-protection. 
McCloskey, D. N. (2016) "How the West (and the Rest) Got Rich." Wall Street Journal (May 20).

National Review Editors (2012) "Professor Freedom." National Review (July 31).

Nordhaus, W. D. (2005) "Schumpeterian Profits and the Alchemist Fallacy Revised." Working Paper No. 6, Yale University, Department of Economics.

Perry, M. J. (2015) "Chart of the Greatest and Most Remarkable Achievement in Human History, Thanks to Free Market Capitalism." American Enterprise Institute (July 13).

Pinkovskiy, M., and Sala-i-Martin, X. (2009) "Parametric Estimations of the World Distribution of Income." NBER Working Paper No. 15433. Available at www.nber.org/papers/w15433.

Reagan, R. (1964) “A Time for Choosing." Speech given on October 27. Available at https://www.reaganlibrary.gov/timechoosing.

Smith, A. (2017) "Record Shares of Americans Now Own Smartphones, Have Home Broadband." Available at www .pewresearch.org/fact-tank/2017/01/12/evolution-of-technology.

U.K. Fin. Conduct Authority (2015) "Regulatory Sandbox." Available at www.fca.org.uk/publication/research/regulatory-sandbox.pdf.

Wright, J. D. (2012) "The Antitrust/Consumer Protection Paradox: Two Policies at War with Each Other." Yale Law Journal 121 (8): 2216-68.

Zywicki, T. J. (2016) "Market-Reinforcing versus Market-Replacing Consumer Finance Regulation." In H. Peirce and B. Klutsey (eds.), Reframing Financial Regulation: Enhancing Stability and Protecting Consumers, 319-41. Arlington, Va.: Mercatus Center, George Mason University. 